\title{
Resources of The Serendipity Society
}

The following is a selection of serendipity publications drawn from a range of fields and disciplines. This page is a continuing work-in-progress. If you have any suggested additions to this list or want to report a broken link, please contact us.

URL: https:// theserendipitysociety.wordpress.com/resources/ (accessed: March 23, 2019)

\section{References:}

Agarwal, N.K. (2015). Towards a definition of serendipity in information behaviour. Information Research, 20(3), paper 675. Retrieved from http://InformationR.net/ir/ 203/pape675.html

Åkerström, M. (2013). Curiosity and serendipity in qualitative research. Qualitative Sociology Review, 9(2): 10-18 [Special Issue: Curiosity and Serendipity in Qualitative Research]. Retrieved from https:// lup.lub.lu.se/ search/publication/ 4434010

Allen, C. M., Erdelez, S. \& Marinov, M. (2013). Looking for opportunistic discovery of information in recent biomedical research: A content analysis. Proceedings of the American Society of Information Science and Technology, 50(1), 1- 11.

André, P. \& schrafel, m.c. (2009). Computing and chance: Designing for(un)serendipity. The Biochemist E-Volution, 31(6), 19-22.

André P., Teevan J ., \& Dumais S.T. (2009). From x-rays to silly putty via Uranus: Serendipity and its role in web search. In Proceedings of the 27th International Conference on Human Factors in Computing Systems (CHI ’09) (pp. 2033-2036).

Andriani, P. (2017). Exaptation, serendipity and aging. Mechanisms of Ageing and Development, 163, 30-35.

Andriani, P. \& Cattani, G. (2016). Exaptation as Source of Creativity, Innovation, and Diversity: Introduction to the Special Section. Industrial and Corporate Change, 25(1), 115-131.

Andriani, P., Ali, A., \& Mastrogiorgio, M. (2017). Measuring Exaptation and Its Impact on Innovation, Search, and Problem Solving. Organization Science, 28(2), 320-338.

Austin, J . H. (2003). Chase, chance, and creativity: The lucky art of novelty. Cambridge: The MIT Press.

Avraham T., Plesser R., \& Nachmias R. (2016). Potentially-serendipitous gain for MOOC participants: A pilot study. In Proceedings of the 3rd Learning With MOOCs Conference (LWMOOCs2016) (in print)

Ban, T.A. (2006). The role of serendipity in drug discovery. Dialogues in Clinical Neuroscience, 8(3): 335-344. Retrieved from https:// www.ncbi.nlm.nih.gov/ pmc/articles/ PMC3181823/ 
Bandura, A. (1982). The psychology of chance encounters and life paths. American Psychologist, 37(7): 747-755. Retrieved from http:// dx.doi.org/ 10.1037/0003$\underline{066 X .37 .7 .747}$

Bardone, E. (2016). Intervening via chance-seeking. pp. 203-220. In: Secchi, Davide \& Neumann, Martin (eds.). Agent-Based Simulation of Organizational Behavior. New Frontiers of Social Science Research. Springer.

Bardone, E. (2017). Learners as chance-seekers. pp. 213-236. In: Allert, Heidrun et al. (eds.]. Digitalität und Selbst: Interdisziplinäre Perspektiven auf Subjektivierungs- und Bildungsprozesse. Transcript Verlag.

Barber, B., \& Fox, R. C. (1958). The case of the floppy-eared rabbits: An instance of serendipity gained and serendipity lost. The American J ournal of Sociology, 64(2), 128-136.

Baumeister, A. A., Hawkins, M. F., \& López-Muñoz, F. (2010). Toward standardized usage of the word serendipity in the historiography of psychopharmacology. J ournal of the History of the Neurosciences, 19, 253- 70.

Bawden, D. (1986). Information systems and the stimulation of creativity. J ournal of Information Science, 12(5): 203-216. doi: 10.1177/016555158601200501

Bawden, D. (2011). Encountering on the road to Serendip? Browsing in new information environments. pp. 1-22. In: Foster, A., \& Rafferty, P. (eds.). Innovations in Information Retrieval: Perspectives for Theory and Practice. London: Facet Publishing. Retrieved from https://hcommons.org/deposits/item/hc:12935/

Beale, R. (2007). Supporting serendipity: Using ambient intelligence to augment user exploration for data mining and web browsing. International J ournal of Human-Computer Studies, 65(5): 421-433. Retrieved from http:// dl.acm.org/citation.cfm?id=1227931

Bedessem, B. \& Ruphy, S. (2016). Serendipity: An argument for scientific freedom? PSA2016: The 25th Biennial Meeting of the Philosophy of Science Association.

Beitman, B.D. (2011). Coincidence Studies. Psychiatric Annals. 41(2): 561-571.

Benjamin, W., Chandrasegaran, S., Ramanujan, D., Elmqvist, N., Vishwanathan, S.V.N. \& Ramani, K. (2014). J uxtapoze: Supporting serendipity and creative expression in clipart compositions. pp. 341-350. Proceedings of the ACM Conference on Human Factors in Computing Systems, CHI 2014, April 26 - May 1, 2014, Toronto, Canada.

Bernier, C.L. (1960). Correlative indexes VI: Serendipity, suggestiveness, and display. American Documentation, 11(4): 277-287. doi: 10.1002/asi.5090110402

Betsworth, D. G., \& Hansen, J .-I. C. (1996). The categorization of serendipitous career development events. J ournal of Career Assessment, 4(1):91-98. 
Björneborn, L. (2017). Three key affordances for serendipity: Toward a framework connecting environmental and personal factors in serendipitous

encounters. J ournal of Documentation, 73(5), 1053-1081. https:// doi.org/ 10.1108/J D07-2016-0097 Preprint here.

Björneborn, L. (2008). Serendipity dimensions and users' information behaviour in the physical library interface. Information Research, 13(4), paper 370. Retrieved from http:// www.informationr.net/ir/ 13-4/paper370.html

Bogers, T., \& Björneborn, L. (2013). Micro-serendipity: Meaningful coincidences in everyday life shared on Twitter. iConference 2013 Proceedings (pp. 196- 208). Retrieved from http:// hdl.handle.net/2142/36052

Bourcier, D. \&van Andel, P. (2017). C’est quoi la serendipité? Le Courrier du Livre.

Bright, J . E. H., Pryor, R. G. L., Chan, E. \& Rijanto, J . (2009). Chance events in career development: Influence, control and multiplicity. J ournal of Vocational Behavior, 75(1), 14- 25. https:// doi.org/ 10.1016/j.jvb.2009.02.007

Bright, J . E. H., Pryor, R. G. L., \&Harpham, L. (2005). The role of chance events in career decision making. J ournal of Vocational Behavior, 66(3), 561-576.

Buchanan, S. (2018). Representation and student research topics: The Archives of Classical Scholarship (ArCla). Paper presented at the 149th Annual Meeting of the Society for Classical Studies, Boston, MA. Retrieved from https:/ / classicalstudies.org/ annual-meeting/ 149/ abstract/ representation-and-studentresearch-topics-archives-classical

Buchem, I. (2011). Serendipitous learning: Recognizing and fostering the potential of microblogging. Formare Open J ournal, no. 74, February/ March 2011. Retrieved from http:// formare.erickson.it/ wordpress/it/ 2011/ serendipitous-learning-recognizing-andfostering-the-potential-of-microblogging/_

Burkell, J ., Quan-Haase, A. \& Rubin, V.L. (2012). Promoting serendipity online: Recommendations for tool design. pp. 525-526. Proceedings of the 2012 iConference, Toronto. New York : ACM. Retrieved from http:// dl.acm.org/ citation.cfm?id=2132274

Burrows, T. and Verhoeven, D. (forthcoming). Serendipity in the digital humanities (under contract with Palgrave)

Busch, C. (2018). How to make the most of serendipity at work. Geneva: World Economic Forum. Retrieved from https:// www.weforum.org/agenda/ 2018/ 07/ how-tomake-serendipity-happen-at-work/

Busch, C., \& Barkema, H.G. (2018). Ecosystem emergence and transformational network leadership: Curating serendipity in high-uncertainty environments. Academy of Management Proceedings. Retrieved from https://journals.aom.org/doi/ 10.5465/AMBPP.2018.16943abstract 
Campanario, J. (1996). Using Citation Classics to study the incidence of serendipity in scientific discovery. Scientometrics, 37(1), 3-24.

Campos, J . A., \& Figueiredo, A. D. (2002). Programming for serendipity. Paper presented at the Proceedings of the 2002 AAAI Fall Symposium. Retrieved from http:// papers.ssrn.com/sol3/papers.cfm?abstract_id=1385402

Campos, J . A., \& Figueiredo, A. D. (2008). Method and system for supporting symbolic serendipity. U.S. Patent No. 7,319,998. Retrieved from http:// pattt.uspto.gov/ netacgi/nphParser?Sect2=PTO1\&Sect2=HITOFF \&p=1\&u=/netahtml/PTO/ searchbool.html\&r=1\&f=G\&l=50\&d=PALL\&RefSrch=yes\&Query=PN/ 7319998

Cannon, W.B. (1940) The role of chance in discovery. The Scientific Monthly 50(3): 204-9.

Carr, P.L. (2015). Serendipity in the stacks: Libraries, information architecture, and the problems of accidental discovery. College \& Research Libraries, 76(6): 831842. https:// doi.org/ 10.5860/ crl.76.6.831

Catellin, S. (2014). Sérendipité. Du conte au concept [Serendipity. From the fairy tale to the concept], Paris, Editions du Seuil, "Science ouverte", 270 p.

Catellin, S. (2012). Sérendipité et réflexivité [Serendipity and reflexivity]. Alliage (Culture, Science, Technique), 70, 74-84.

Catellin, S. \& Loty, L. (2013). Sérendipité et indisciplinarité [Serendipity and indisciplinarity]. Hermès, nº67, Paris, CNRS Éditions, 32-40.

Chan, S. (2007). Tagging and searching: Serendipity and museum collection databases. Proceedings of Museums and the Web 2007. San Francisco, CA: Archives and Museum Informatics. Retrieved from http://www.archimuse.com/mw2007/papers/chan/chan.html

Coleman, S.L. \& Beitman, B.D. (2009). Characterizing High-frequency Coincidence Detectors. Psychiatric Annals. 39(5)

Coleman, S.L., Beitman, B.D. \&Celebi E. (2009). Weird Coincidences Commonly Occur. Psychiatric Annals. 39(5)

Copeland, S. (2018). "Fleming Leapt on the Unusual like a Weasel on a Vole": Challenging the Paradigms of Discovery in Science. Perspectives on Science. 26(6)

Copeland, S. (2017). On Serendipity in Science: Discovery at the Intersection of Chance and Wisdom. Synthese, online first https:// doi.org/ 10.1007/s11229-017$\underline{1544-3}$

Copeland, S. (2015). The Case of the Triggered Memory: Serendipitous Discovery and the Ethics of Clinical Research. PhD Thesis: Dalhousie University, Department of Philosophy. Retrieved from https:/ dalspace.library.dal.ca/ handle/ 10222/63140 
Cunha, M. P. e. (2005). Serendipity: Why some organizations are luckier than others. FEUNL Working Paper No. 472. Retrieved from http:// dx.doi.org/ 10.2139/ssrn.882782

Cunha, M. P. e., Clegg, S. R., \& Mendonça, S. (2010). On Serendipity and Organizing. European Management J ournal 28: 319- 30. doi:10.1016/j.emj.2010.07.001.

Dantonio, L., Makri, S. \& Blandford, A. (2012). Coming across academic social media content serendipitously. Proceedings of the American Society for Information Science and Technology, 49(1), pp. 1-10.

Danzico, L. (2010). The design of serendipity is not by chance. Interactions, 17(5): 16-18. Retrieved from http://interactions.acm.org/archive/view/ september-october-2010/thedesign-of-serendipity-is-not-by-chance1

Darbellay, F., Moody, Z., Sedooka, A., \& Steffen, G. (2014). Interdisciplinary Research Boosted by Serendipity. Creativity Research J ournal, 26(1): 1- 10. doi:10.1080/ 10400419.2014.873653.

de Bruijn, O. \& Spence, R. (2008). A new framework for theory-based interaction design applied to serendipitous information retrieval. ACM Transactions on Computer-Human Interaction, 15(1): article no. 5. Retrieved from http:// portal.acm.org/ citation.cfm?id=1352782.1352787

de Rond, M. (2014). The structure of serendipity. Culture and Organization [special issue on serendipity], 20(5): 342-358. https:// doi.org/ 10.1080/14759551.2014.967451

de Rond, M., \&Morley, I. (eds.) (2010). Serendipity: Fortune and the prepared mind. Cambridge University Press.

Deuschel, T., Heuss, T., Humm, B. \& Frölich, T. (2014). Finding without searching - A serendipity-based approach for digital cultural heritage. Proceedings of the International Conference on Digital Intelligence (DI 2014), Nantes, France.

Dew, N. (2009). Serendipity in entrepreneurship. Organization Studies, 30(7): 735-753. Retrieved from http:/ / www.effectuation.org/wp-content/ uploads/ 2017/ 06/ Serendipity1.pdf

Díaz de Chumaceiro, C.L.D. (1997). Serendipity citations in the biomedical sciences. Creativity Research J ournal, 10(1):91-93.

Díaz de Chumaceiro, C.L.D. (1999). Sortes Walpolianae: Discoveries “Almost” Like Serendipity. Creativity Research J ournal, 12(4), 339-341. doi 10.1207/s15326934crj1204_12

Duff, W.M. \&J ohnson, C.A. (2002). Accidentally found on purpose: Informationseeking behavior of historians in archives. Library Quarterly, 72(4): 472-496.

Eco, U. (1998). Serendipities: Language \& lunacy. New York: Columbia University Press. 
Erdelez, S. (1996). Information encountering on the Internet. In M. Williams (Ed.), Proceedings of the 17th National Online Meeting (pp. 101-107). Medford, NJ : Information Today.

Erdelez, S. (1997). Information Encountering: A conceptual framework for accidental information discovery. In P. Vakkari, R. Savolainen, \& B. Dervin (Eds.), Information Seeking in Context. Proceedings of an International Conference on Research in Information Needs, Seeking and Use in Different Contexts (pp. 412-421). London: Taylor Graham.

Erdelez, S. (1999). Information encountering: It's more than just bumping into information. Bulletin of the American Society for Information Science, 25(3):25-29.

Erdelez, S. (2000). Towards understanding information encountering on the Web. Proceedings of the Annual Meeting of the American Society for Information Science, 47, 363-371.

Erdelez, S. (2004). Investigation of an opportunistic acquisition of information in the controlled research environment. Information Processing \& Management 40, 1013-1025.

Erdelez, S. (2005). Information encountering. In K. E. Fisher, S. Erdelez \& L. McKechnie (Eds.), Theories of information behavior (pp. 179-185). Medford, NJ : Information Today.

Erdelez, S., \& Rioux, K. (2000). Sharing information encountered for others on the Web. The New Review of Information Behavior Research, 1, 219-233.

Erdelez, S., Basic, J . \& Levitov, D.D. (2011). Potential for Inclusion of Information Encountering within Information Literacy Models. Information Research. 16(3): 489.

Fine, G. A., \&Deegan, J . G. (1996). Three principles of Serendip: Insight, chance, and discovery in qualitative research. International J ournal of Qualitative Studies in Education, 9(4), 434-447.

Foster, A. \& Ellis, D. (2014). Serendipity and its study. J ournal of Documentation, 70(6): 1015-1038. doi: 10.1108/J D-03-2014-0053

Foster, A., \& Ford, N. (2003). Serendipity and information seeking: An empirical study. J ournal of Documentation, 59(3), 321-340.

Gabriel, Y., Muhr, S.L. \&Linstead, S. (2014). Luck of the draw? Serendipity, accident, chance and misfortune in organization and design. Culture and Organization [special issue on serendipity], 20(5): 334-341. doi: 10.1080/ 14759551.2014.967452

Garfield, E. (2004). Systematic serendipity: Finding the undiscovered answers to science questions. Presentation at the Medical Ignorance Collaboratory, University of Arizona, Tucson. Retrieved from http:// www.garfield.library.upenn.edu/ papers/ az072004.pdf 
Garud, R., Gehman, J ., and Giuliani, A.P. (2018). Serendipity arrangements for exapting science-based innovations. Academy of Management Perspectives, 32(1): 125140. https:// doi.org/ 10.5465/amp.2016.0138

Garud, R., Gehman, J . Giuliani, A. 2016. Technological Exaptation: A Narrative Approach. Industrial and Corporate Change, 25(1), 149-166.

Garud, R. Nayyar. P., and Shapira, Z. 1997. "Beating the odds: Towards a theory of technological innovation" in Garud, R. Nayyar, P. and Shapira, Z. (eds.) Technological innovation: oversights and foresights, Cambridge University Press, Cambridge, UK, pp: 20-40.

Ge, M., Battenfeld, C.D. \&J annach, D. (2010). Beyond accuracy: Evaluating recommender systems by coverage and serendipity. pp. 257-260. Proceedings of the fourth ACM conference on Recommender systems, 2010. Retrieved from https:// dl.acm.org/ citation.cfm?doid=1864708.1864761

Gest, H. (1997). Serendipity in scientific discovery: A closer look. Perspectives in Biology and Medicine, 41(1), 21- 28.

Hagel, J ., Brown, J .S., \& Davison, L. (2010) The Power of Pull: How Small Moves Smartly Made Can Set Big Things in Motion. New York: Basic Books.

Hagel, J ., Brown, J .S., \& Davison, L. (2010). Shaping serendipity: Volume 2. Deloitte. Retrieved from https:// www2.deloitte.com/ content/ dam/ Deloitte/ us/ Documents/technology-mediatelecommunications/us-tmt-ce-ShapingSerendipityVol2-09192014.pdf

Heinström, J . (2006). Psychological factors behind incidental information acquisition. Library \& Information Science Research, 28(4), 579-594.

Hotson, L. (1942). Literary serendipity. ELH - A J ournal of English Literary History, 9(2): 79-94. Retrieved from http:// www.jstor.org/ stable/ 2871761

Iaquinta, L., Marco de Gemmis, M., Lops, P., Semeraro, G. \&Molino, P. (2011). Motivating serendipitous encounters in museum recommendations. pp 159-167. In: V. Pallotta et al. (eds.). Advances in Distributed Agent-Based Retrieval Tools. Springer. Retrieved from https:// doi.org/ 10.1007/978-3-642-21384-7 11

J effrey, P. \& McGrath, A. (2000). Sharing serendipity in the workplace. pp. 173-179. Proceedings of the Third International Conference on Collaborative Virtual Environments, San Francisco. New York: ACM. Retrieved from http://portal.acm.org/ citation.cfm?id=351006.351037

Kaag, J . (2008). Chance and creativity: The nature of contingency in classical American philosophy. Transactions of the Charles S. Peirce Society, 44(3): 393-411. Retrieved from http:// www.jstor.org/ stable/40321319 
Kakko, I. \& Inkinen, S. (2009). Homo creativus: creativity and serendipity management in third generation science and technology parks. Sci Public Policy, 36(7): 537-548.

Kakko, I. (2014). Oasis Way and the Post-Normal Era- How Understanding Serendipity Will Lead You to Success. St. Petersburg: BHV. [Online here]

Kantorovich, A. K. (1993). Scientific discovery: Logic and tinkering. New York: SUNY Press.

Kantorovich, A. \& Ne'eman, Y. (1989). Serendipity as a source of evolutionary progress in science. Studies in History and Philosophy of Science, 20(4): 505-529.

Kennedy, P. (2016). Inventology: How we dream up things that change the world. Eamon Dolan/ Houghton Mifflin Harcourt.

Khalili, A., van Andel, P., van den Besselaar, P. \& de Graaf, K.A. (2017). Fostering serendipitous knowledge discovery using an adaptive multigraph-based faceted browser. K-CAP 2017 Proceeding of the Knowledge Capture Conference, Article No.15. https:// dl.acm.org/ citation.cfm?id=3148037

Kim, H.M., Ghiasi, B., Spear, M., Laskowski, M. \& Li, J . (2017). Online serendipity: The case for curated recommender systems. Business Horizons, 60(5): 613-620. Retrieved from https:// doi.org/ 10.1016/j.bushor.2017.05.005

LeClerc, A. (2010). Seeking serendipity: The inspiration hunt of a creative professional. Faculty of Information Quarterly, 2(3), 1-8.

Leong, T.W. (2009). Understanding serendipitous experiences when interacting with personal digital content. $\mathrm{PhD}$ thesis. Department of Information Systems, University of Melbourne. Retrieved from https://trove.nla.gov.au/version/48777438

Leong, T.W., Harper, R. \& Regan, T. (2011). Nudging towards serendipity: A case with personal digital photos. pp. 385-394. Proceedings of the 25th BCS Conference on Human-Computer Interaction, BCS-HCI '11. Retrieved from http:// dl.acm.org/citation.cfm?id=2305382

Leong, T.W., Vetere, F. \& Howard, S. (2005). The Serendipity Shuffle. Proceedings of the 19th CHISIG of Australia on Computer-Human Interaction, OZCHI '05 Canberra, Australia. Retrieved from https:// dl.acm.org/ citation.cfm?id=1108428

Lenox, R. S. (1985). Educating for the serendipitous discovery. J ournal of Chemical Education, 62(4), 282.

Liestman, D. (1992). Chance in the midst of design: Approaches to librarian research serendipity. Research Quarterly, 31(4), 524-532.

Lindsay, G.(2013, April 5). Engineering serendipity. New York Times. Retrieved from http:// www.nytimes.com/2013/ 04/ 07/ opinion/sunday/ engineering-serendipity.html 
Lindsay, G. (2015, J uly 9). How to engineer serendipity. Time. Retrieved from http:// time.com/3951029/ engineer-serendipity/

López, G. (2009). Serendipity - ¿Por Qué Algunos Tienen Éxito Y Otros No? Alienta editorial.

Luczak-Rösch, M., Tinati, R., Simperl, E., Kleek, M. V., Shadbolt, N., and Simpson, R. Why won't aliens talk to us? content and community dynamics in online citizen science. In Eighth International AAAI Conference on Weblogs and Social Media (2014). Available at: https:// eprints.soton.ac.uk/363523/1/ document.pdf

Lutz, C., Hoffmann, C.P. \& Meckel, M. (2017). Online serendipity: A contextual differentiation of antecedents and outcomes. J ournal of the Association for Information Science and Technology, 68(7): 1698-1710. DOI: 10.1002/asi.23771

Maddox, A. (September 14, 2015). Serendipity: Social Mobility Across Social Networks and Networked Digital Technologies. Avail. at

SSRN: https:// ssrn.com/abstract=2756287

Magnani, L., Arfini, S., \& Bertolotti, T. (2016). An argument for ignorance-based chance discovery. International J ournal of Advanced Intelligence Paradigms, 8(3), 327-342.

Makri, S., \& Blandford, A. (2012). Coming across information serendipitously: Part 1 (A process model). J ournal of Documentation, 68(5), 684-705.

Makri, S. \& Blandford, A. (2012). Coming across information serendipitously: Part 2 (A classification framework). J ournal of Documentation, 68(5), 706-724.

Makri, S., Blandford, A., Woods, M., Sharples, S., \&Maxwell, D. (2014). “Making my own luck": Serendipity strategies and how to support them in digital information environments. J ournal of the Association for Information Science \& Technology, 65(11), 2179-2194.

Maloney, A. \&Conrad, L.Y. (2016). Expecting the unexpected: Serendipity, discovery, and the scholarly research process. A SAGE White Paper. Thousand Oaks, CA.: SAGE Publishing.

Malmelin, N. \&Virta, S. (2017). Seizing the serendipitous moments: Coincidental creative processes in media work. J ournalism, OnlineFirst May 18, 2017. Retrieved from http:/ / doi.org/ 10.1177/ 1464884917707121.

Martin, K., Greenspan, B. \& Quan-Haase, A. (2017). STAK - Serendipitous tool for augmenting knowledge: A conceptual tool for bridging digital and physical resources. Digital Studies, 7(1). URL:

https:// www.digitalstudies.org/ articles/ 10.16995/ dscn.265/

Martin, K., \&Quan-Haase, A. (2017). “A Process of Controlled Serendipity”: An Exploratory Study of Historians' and Digital Historians' Experiences of Serendipity in Digital Environments. In 80th Annual Meeting of the Association 
for Information Science \& Technology (pp. 289-297). Washington, D.C.: ACM Press. Retrieved from https://ir.lib.uwo.ca/ cgi/viewcontent.cgi?article=1243\&context=fimspub

Martin, K., \&Quan-Haase, A. (2016). The role of agency in historians' experiences of serendipity in physical and digital information environments. J ournal of Documentation, 72(6), 1008- 1026. http:// dx.doi.org/ 10.1108/JD-11-2015-0144

Martin, K., \&Quan-Haase, A. (2013). Are e-books substituting print books? Tradition, serendipity, and opportunity in the adoption and use of e-books for historical research and teaching J ournal of the American Society for Information Science, 64(5), 1016-1028.

Maxwell, D., Woods, M., Makri, S., Bental, D., Kefalidou, G., \& Sharples, S. (2012). Designing a semantic sketchbook to create opportunities for serendipity. In Proceedings of the $26^{\text {th }}$ Annual BCS Interaction Specialist Group Conference on People and Computers, 357- 362. Retrieved from http:// ewic.bcs.org/ content/ ConWebDoc/ 47823

McBirnie, A. (2008). Seeking serendipity: The paradox of control. ASLIB Proceedings, 60(6), 600-618.

McBirnie, A. (2012). A Descriptive Profile of Process in Serendipity: A Narrative and Network Study of Information Behaviour in Context. PhD Thesis: Aberystwyth University, Department of Information Studies. Retrieved from http:// cadair.aber.ac.uk/ dspace/ handle/2160/13507

McBirnie, A., \& Urquhart, C. (2011). Motifs: dominant interaction patterns in event structures of serendipity. Information Research, 16(3). Retrieved from http://InformationR.net/ir/ 16-3/paper494.html

McCay-Peet, L. (2013). Investigating Work-Related Serendipity, What Influences It, and How It May Be Facilitated in Digital Environments. PhD dissertation. Dalhousie University, Halifax, Canada. Retrieved from http:// hdl.handle.net/ 10222/42727

McCay-Peet, L. \&Toms, E.G. (2015). Investigating serendipity: How it unfolds and what may influence it. J ournal of the Association for Information Science and Technology, 66(7), 1463-1476.

McCay-Peet, L. \& Toms, E.G. (2017). Researching Serendipity in Digital Information Environments. Morgan \& Claypool Publishers.

McCay-Peet, L., Toms, E.G. \& Kelloway, E.K. (2015). Examination of relationships among serendipity, the environment, and individual differences. Information Processing and Management, 51(4), 391-412.

McCay-Peet, L. \& Wells, P.G. (2017). Serendipity in the sciences: Exploring the boundaries. Proceedings of the Nova Scotian Institute of Science (PNSIS), 49(1), 97116. 
Merton, R. K. (1948). The bearing of empirical research upon the development of social theory. American Sociological Review, 13 (5): 505- 15.

Merton, R. K., \& Barber, E. (2004). The travels and adventures of serendipity: A study in sociological semantics and the sociology of science. Princeton, $\mathrm{NJ}$ : Princeton University Press.

Michener, W. K., Bildstein, K. L., McKee, A., Parmenter, R. R., Hargrove, W. W., McClearn, D., \& Stromberg, M. (2009). Biological field stations: Research legacies and sites for serendipity. BioScience, 59 (4): 300- 310. doi:10.1525/ bio.2009.59.4.8.

Miwa, M., Egusa, Y., Saito, H., Takaku, M., Terai, H. \& Kando, N. (2011). A method to capture information encountering embedded in exploratory Web searches. Information Research, 16(3) paper 487. Retrieved from http://InformationR.net/ir/ 163/paper487.html

Moghnieh, A., Arroyo, E. \& Blat, J . (2008). The News Wall: Serendipitous discoveries in dynamic information spaces. Proceedings of IUI'08.

Murakami, T, Mori, K. \& Orihara, R. (2008). Metrics for evaluating the serendipity of recommendation lists. New Frontiers in Artificial Intelligence, vol. 4914, pp. 40-46. Retrieved from https:// dl.acm.org/ citation.cfm?id=1788320

Murayama, K., Nirei, M., \& Shimizu, H. (2015). Management of science, serendipity, and research performance: Evidence from a survey of scientists in J apan and the U.S. Research Policy 44, 862- 73.

Napier, N.K. \&Vuong, Q.H. (2013). Serendipity as a strategic advantage? pp. 175-199. In: T.J. Wilkinson \&V.R. Kannan (eds.). Strategic Management in the 21st Century. ABCCLIO, LLC, Santa Barbara, CA.

Napolitano, C. M. (2013). More than just a simple twist of fate: Serendipitous relations in developmental science. Human Development, 56 (5): 291- 318. doi:10.1159/000355022.

Niu, X., \& Abbas, F. (2017). A framework for computational serendipity. In Proceedings of the $25^{\text {th }}$ Conference on User Modeling, Adaptation, and Personalization (UMAP 2017). Bratislava, Slovakia. J uly 9-12.

Niu, X., Abbas, F., Maher, M. \& Grace, K. (2018). Surprise Me If You Can: Serendipity in Health Information. Accepted to the Proceedings of the ACM CHI Conference on Human Factors in Computing Systems (ACM CHI 2018). Montreal, Canada, April 2126, 2018.

Nutefall, J . E., \& Ryder, P. M. (2010). The serendipitous research process. The J ournal of Academic Librarianship, 36(3), 228-234.

Olma, S. (2016). In Defence of Serendipity: For a Radical Politics of Innovation. London: Repeater Books. 
Palagi, E. (2018). Evaluating exploratory search engines: designing a set of usercentered methods based on a modeling of the exploratory search process. $\mathrm{PhD}$ Thesis - Human-Computer Interaction, Université Côte d'Azur. https:// tel.archives-ouvertes.fr/tel-01976017

Palagi, E., Gandon, F., Giboin, A. \& Troncy, R. (2018). A Model-based Heuristic Evaluation Method of Exploratory Search. HCI 2018 - 32nd British Computer Interaction Conference, J uly 2018, Belfast, UK, pp. 1-5. https:// hal.archives-ouvertes.fr/hal$\underline{01834292}$

Pálsdóttir, Á. (2010). The connection between purposive information seeking and information encountering: A study of Icelanders' health and lifestyle information seeking. J ournal of Documentation, 66(2), 224-244.

Pálsdóttir, Á. (2011). Opportunistic discovery of information by elderly Icelanders and their relatives. Information Research, 16(3), paper 485. Retrieved from http:// www.informationr.net/ir/ 16-3/paper485.html

Panahi, S., Watson, J . \& Partridge, H. (2015). Information encountering on social media and tacit knowledge sharing. J ournal of Information Science, 42(4): 539-550. doi: $10.1177 / 0165551515598883$

Pryor, R.G.L. \& Bright, J.E.H. (2011). Chaos theory of careers. Routledge. New York.

Race, T.M. \&Makri, S. (eds.) (2016). Accidental Information Discovery: Cultivating Serendipity in the Digital Age. Elsevier.

Reviglio, U. (2019). Serendipity as an emerging design principle of the infosphere: Challenges and opportunities. Ethics and Information Technology. First online J an.2 https://link.springer.com/article/ 10.1007/s10676-018-9496-y

Reviglio, U. (2017). Serendipity by Design? How to Turn from Diversity Exposure to Diversity Experience to Face Filter Bubbles in Social Media. In: Kompatsiaris I. et al. (eds) Internet Science. INSCI 2017. Lecture Notes in Computer Science, vol 10673. Springer, Cham. https://doi.org/10.1007/ 978-3-319-70284-1_22

Rice, J . (1988). Serendipity and holism: The beauty of OPACs. Library J ournal, 113(3), 138-141.

Roberts, R.M. (1989). Serendipity : Accidental Discoveries in Science. NewYork: J ohn Wiley \& Sons.

Rosenman, M.F. (1988). Serendipity and scientific discovery. J ournal of Creative Behavior, 22(2): 132-138. doi: 10.1002/j.2162-6057.1988.tb00674.x

Ross, C.S. (1999). Finding Without Seeking: The information encounter in the context of reading for pleasure. Information Processing and Management, 35, 783-799. 
Rubin, V. L., Burkell, J ., \& Quan-Haase, A. (2011). Facets of serendipity in everyday chance encounters: a grounded theory approach to blog analysis. Information Research, 16(3), paper 488. Retrieved form http:// www.informationr.net/ir/ 163/paper488.html

Sauer, S. (2013). User Innovativeness in Living Laboratories - Everyday User Improvisations with ICTs as a Source of Innovation. $\mathrm{PhD}$ Thesis: University of Twente.

Sauer, S. (currently under review). Searching for a story: Creative retrieval practices of media professionals," IAMCR 2016: International Association for Media and Communication Research, 27-31J uly, Leicester, UK .

Sauer, S., \&De Rijke, M. (2016). Seeking serendipity: A living lab approach to understanding creative retrieval in broadcast media production. SIGIR 2016: 39th International ACM SIGIR Conference on Research and Development in Information Retrieval. ACM.

Sawaizumi, S., Katai, O., Kawakami, H., \& Shiose, T. (2007, November). Using the concept of serendipity in education. Paper presented at the KICSS 2007: The Second International Conference on Knowledge, Information and Creativity Support Systems, Nomi, Ishikawa, J apan. Retrieved from https:// dspace.jaist.ac.jp/dspace/ handle/ 10119/4087

Silver, S. (2015). The prehistory of serendipity, from Bacon to Walpole. Isis, 106(2), 235- 56. doi:10.1086/681977.

Solomon, Y. (2017). Temporal aspects of info-serendipity. Temporalités - Revue de Sciences Sociales et Humaines, 24, paper 3523. Retrieved from: http:// temporalites.revues.org/ 3523?lang=en

Solomon, Y., \& Bronstein, J. (2016). Serendipity in legal information seeking behavior: Chance encounters of family-law advocates with court rulings. Aslib J ournal of Information Management, 68(1), 112-134. doi: 10.1108/ AJ IM-04-2015-0056.

Stewart, K.N. \& Basic, J . (2014). Information encountering and management in information literacy instruction of undergraduate students. International J ournal of Information Management, 34: 74-79. https:// doi.org/ 10.1016/j.jinfomgt.2013.10.007

Sun, X., Sharples, S., \&Makri, S. (2011). A user-centred mobile diary study approach to understanding serendipity in information research. Information Research, 16 (3), paper 492. Retrieved from http:// www.informationr.net/ir/ 16-3/ paper492.html

Sun, T., Zhang, M. \& Mei, Q. (2013). Unexpected relevance: An empirical study of serendipity in retweets. 7th International AAAI Conference on Weblogs and Social Media, ICWSM 2014.

Taleb, N.N. (2007). The black swan: The impact of the highly improbable. Allen Lane. 
Tamboukou, M. (2015). Feeling narrative in the archive: the question of serendipity. Qualitative Research, 16(2), 151-166. doi: 10.1177/ 1468794115569563

Taramigkou, M., Bothos, E., Christidis, K., Apostolou, D. \&Mentzas, G. (2013). Escape the bubble: Guided exploration of music preferences for serendipity and novelty. pp. 335-338. Proceedings of the 7th ACM conference on Recommender systems, RecSys '13. ACM. doi: 10.1145/2507157.2507223

Taramigkou, M., Apostolou, D., \&Mentzas, G. (2017). Supporting creativity through the interactive exploratory search paradigm. International J ournal of HumanComputer Interaction, 33(2), 94-114.

Tewksbury, D., Weaver, A. J ., \&Maddex, B. D. (2001). On the web - accidentally informed: Incidental news exposure on the world wide web. J ournalism \& Mass Communication Quarterly, 78(3), 533-554.

Thom-Santelli, J . (2007). Mobile social software: Facilitating serendipity or encouraging homogeneity. Pervasive Computing, 6(3): 46-51.

Thudt, A., Hinrichs, U., \& Carpendale, S. (2012). The bohemian bookshelf. In J. Kjeldskov and M.B. Skov (Eds.), Proceedings of the SIGCHI Conference on Human Factors in Computing Systems (pp. 1461-1470). New York, NY: ACM Press. doi: $10.1145 / 2207676.2208607$

Tinati, R., Van Kleek, M., Simperl, E., Luck-Rösch, M., Simpson, R., \& Shadbolt, N. (2015). Designing for citizen data analysis: A cross-sectional case study of a multidomain citizen science platform. In Proceedings of the 33rd Annual ACM Conference on Human Factors in Computing Systems (pp. 4069-4078). ACM. doi: $\underline{10.1145 / 2702123.2702420}$

Toms, E.G. (2000). Serendipitous information retrieval. p. 11-12. Proceedings of the First DELOS Network of Excellence Workshop on Information Seeking, Searching and Querying in Digital Libraries, Zurich, Switzerland. Retrieved October 16, 2016 from http:// www.ercim.eu/publication/ws-proceedings/DelNoe01/3 Toms.pdf

Toms, E. G. (2000). Understanding and facilitating the browsing of electronic text. International J ournal of Human-Computer Studies, 52(3), 423-452.

Toms, E.G. \& McCay-Peet, L. (2009). Chance encounters in the digital library. In M. Agosti, J ., et al. (Eds.), Lecture Notes in Computer Science: Research and Advanced Technology for Digital Libraries, ECDL 2009, Corfu, Greece (Vol. 5714, pp. 192-202). New York: Springer-Verlag.

Van Andel, P. (1994). Anatomy of the unsought finding. Serendipity: Origin, history, domains, traditions, appearances, patterns and programmability. British J ournal for the Philosophy of Science, 45(2), 631-648.

Verhoeven, D. (2016). As luck would have it: Serendipity and solace in digital research infrastructure. Feminist Media Histories (special issue on Archives and Archivists), 2(1), 7-28. 
Verhoeven, D., and Burrows, T. (2014, December 10). Crowdsourcing for serendipity. The Australian (Higher Education), 1-3.

Verhoeven, D. \& de Costa V. (2014). HuNI: Helping humanities researchers get lucky [moving image]. Retrieved from http:// vimeo.com/ bestqualitycrab/huniserendipity

Walpole, H. (1754/ 1960). Letter to Horace Mann, January 28. In: W.S. Lewis (ed.). The Correspondence of Horace Walpole. The Yale Edition, Vol. 20, pp. 407-409. New Haven, CT: Yale University Press, 1960.

Waugh, S., McKay, D. \& Makri, S. (2017). 'Too much serendipity': The tension between information seeking and encountering at the library shelves. pp. 277-280. Proceedings of the 2017 Conference on Human Information Interaction and Retrieval CHIIR '17. New York: ACM Press. Retrieved from http:// openaccess.city.ac.uk/ 17102/

Williamson, K. (1998). Discovered by chance: The role of incidental information acquisition in an ecological model of information use. Library and Information Science Research, 20(1), pp. 23-40.

Williamson, K. (2005). Ecological theory of human information behavior. In K. E. Fisher, S. Erdelez \& L. McKechnie (Eds.), Theories of Information Behavior (pp. 128132). Medford, NJ : Information Today.

Woods, M. (2014). Serendipity in practice : A social state. pp. 176-181. In: A. Williams et al. (eds.). BITE: Recipes for Remarkable Research. Sense Publishers.

Wopereis, I., \& Braam, M. (2018). Seeking serendipity: The art of finding the unsought in professional music. Communications in Computer and Information Science, 810, 503-512. doi:10.1007/978-3-319-74334-9_52

Workman, T. E., Fiszman, M., Rindflesch, T. C. \&Nahl, D. (2014). Framing serendipitous information-seeking behavior for facilitating literature-based discovery: $A$ proposed model. J ournal of the Association for Information Science and Technology, 65(3): 501-512. doi: 10.1002/asi.22999

Yadamsuren, B., \& Erdelez, S. (2016). Incidental exposure to online news. Synthesis Lectures on Information Concepts, Retrieval, and Services, 8(5), i-73. doi: 10.2200/ S00744ED1V01Y201611ICR054

Yadamsuren, B. \& Erdelez, S. (2011). Online news reading behavior: From habitual reading to stumbling upon news. Proceedings of the American Society for Information Science and Technology (ASIS\&T), 48(1), 1-10.

Yadamsuren, B., \& Erdelez, S. (2010). Incidental exposure to online news. Proceedings of the American Society for Information Science and Technology, 47(1), 1-8.

Yadamsuren, B., Erdelez, S., Lee, J . \& Thorson, E. (2011). Incidental Exposure to Online News: An Insight from the Pew Internet Project. Proceedings of the Association for Education in J ournalism and Mass Communication (AEJ MC). 
Yadamsuren, B. \& Heinström, J . (2011). Emotional reactions to incidental exposure to online news. Information Research, 16(3) paper 486. [Available at http://InformationR.net/ir/ 16-3/ paper486.html\%5D

Yaqub, O. (in press). Serendipity: Toward a Taxonomy and a Theory. Research Policy. https:// doi.org/ 10.1016/j.respol.2017.10.007

Zhang, Y., Séaghdha, D., Quercia, D., \&J ambor, T. (2012). Auralist: Introducing serendipity into music recommendation. Proceedings of the 5th ACM Conference on Web Search and Data Mining, WSDM-12, Seattle. Retrieved from http:// www.cs.ucl.ac.uk/fileadmin/UCL-CS/research/Research_Notes/RN 11 21.pdf

Zhou, X., Sun, X., Wang, Q. \& Sharples, S. (2018). A context-based study of serendipity in information research among Chinese scholars. J ournal of Documentation. https:// doi.org/ 10.1108/JD-05-2017-0079

Zuckerman, E. (2011). Desperately seeking serendipity. Keynote at the ACM CHI Conference on Human Factors in Computing Systems (CHI 2011), May 7-12, 2011, Vancouver, Canada. Retrieved from http:// www.ethanzuckerman.com/blog/2011/ 05/12/ chi-keynote-desperately-seekingserendipity/ 